INTERDISCIPLINARIA ARCHAEOLOGICA NATURAL SCIENCES IN ARCHAEOLOGY

News and views

\title{
Forest, Wood, and Ancient Man
}

\author{
Manfred Rösch ${ }^{\mathrm{a}^{*}}$ \\ ${ }^{a}$ Landesamt für Denkmalpflege im RP Stuttgart, Fischersteig 9, D-78343 Gaienhofen-Hemmenhofen, Germany
}

\section{ARTICLE INFO}

\section{Article history:}

Received: 30 March 2012

Accepted: 10 October 2012

\section{Keywords:}

wood growth

wood consumption

Neolithic

pollen and wood analysis

\begin{abstract}
$A B S T R A C T$
Under natural conditions, temperate Europe would be completely covered with forests. After several millennia of human impact, large parts of these forests have disappeared. The disturbance and disappearance of these forests has been primarily caused by crop and animal husbandry. This paper will argue that, at least during the Neolithic, the demand for wood for fuel and construction had no influence on the forests because the amount of wood needed was much smaller than the natural production. If there was any deforestation or changes in the forest cover indicated, it was caused by animal and crop husbandry and not by timber exploitation. This is demonstrated by calculations and by comparing onsite wood analysis and off-site pollen results from Lake Constance. They reveal no correlation between the specific use of wood and the changes to these species in the pollen record.
\end{abstract}

\section{Introduction}

Plants compete for light, space, water, and nutrients (Strasburger 1983). Under suitable environmental conditions such as a moderate, humid climate and rich soils, the most persistent and tallest species producing the darkest shade are the winners. Other species have to find their position in less suitable, unfavourable habitats.

This is the situation in the forest, and the trees of the forest are the dominating phenotype of the temperate zones where the climate is neither too dry nor too cold for tree growth. The individual tree is continually gaining in height and accumulating biomass until it dies. The primary forest has an oscillating equilibrium in terms of height, medium age and biomass (Braun 1982; Ellenberg 1996).

The young period, when the tree is still in the shade of older trees, is the most important phase for inter-specific competition. For example, Abies alba is, at least in the mountain regions of south-western Central Europe, under suitable conditions, the strongest competitor among the trees of temperate Europe. This is not only as a result of its possible height, age, and dark shade but in particular due to its shadow tolerance when young. It can therefore even displace other trees under suboptimal, for example, too dry

"Corresponding author. E-mail: manfred.roesch@rps.bwl.de conditions, where it is not able to reach its maximum height and age (Hegi 1981).

With the exception of a small number of evergreen species, trees of temperate zones survive the cold season by shedding their leaves. In order to achieve its considerable height, a tree needs several years and must also enlarge its diameter. The yearly biomass production of a forest and a meadow can be more or less the same, whereas the biomass on the surface of a meadow is destroyed in the same or at the latest in the following year; the forest accumulates its biomass as wood over many years. (Walter, Breckle 1983).

\section{The primary forest during the Neolithic and Bronze Age. The composition based on the species and age of the trees}

During the Neolithic when humans began to use, change or remove the forest, the strongest competitors, the so-called shade trees, Picea, Carpinus, Fagus, Abies, had begun to replace the mixed oak forest. During the Bronze Age this process was completed with the exception of the northernmost parts of Central Europe and of Northern Europe (Lang 1994). The primary forests of that time have disappeared completely. We can obtain an extremely vague impression of their structure in small patches of forests which have been growing without forest management and significant human 
impact for decades or even centuries, for example, the Forest of Bialowiecza in Poland, the Rotwald near Lunz in Austria or the so-called Bannwälder, established by the forest administration of Baden-Württemberg in the last century (Leibundgut 1982, 1993; Lopez, Bücking 1994). In contrast to a forest used for wood production, a primary forest consists of a diversity of tree species with trees at all states of growth. The life cycle of the primary forest is not homogeneous over a large area, but only in small patches: only where an old tree dies can young trees and seedlings compete for light and nutrients and as such start a new succession.

\section{The productivity of temperate forests under different conditions}

As already stated, trees accumulate biomass as wood on the surface by growing in length as well as in thickness. Wood is a complex material consisting of different cells and tissues, partly living, partly dead. It has specific qualities in regard to hardness, flexibility, weight and endurance. Various species therefore differ in their suitability for different purposes.

Precise data regarding the wood stock and its annual increase in primary forests is lacking, although we can refer to data from modern working forests, consisting of only one age class (Kramer 1988; Mitscherlich 1978; Röhrig et al. 2006). The annual growth depends on the tree species, the age of the trees and environmental factors, in particular soil and climate. Based on these environmental factors, forest science distinguishes different quality classes of wood growth. In the first class, the medium annual accumulation of thick wood, without roots, twigs and branches is dependent on the harvest age and differs between $12.2 \mathrm{~m}^{3}$ for Picea abies and $4.9 \mathrm{~m}^{3}$ for Betula pendula (Table 1). The stem wood available per ha, given a harvest age between 60 (Alnus gluinosa) and 160 years (Quercus robur/petraea), is between $212 \mathrm{~m}^{3}$ (Betula) and $836 \mathrm{~m}^{3}$ (Abies alba aged 140 years). This data refers to the first quality class. The poorer classes have less wood growth. For Western Germany, for example, Mayer (1984) mentions a medium value of $4.8 \mathrm{~m}^{3}$ per year. These calculations are based on strong wood which can be eventually harvested. A loss of weaker wood during the growth period of the forest by thinning or dying of trees is not included. The growth of a freshly planted forest begins with approximately 5000 young trees per ha and ends after 100 years with a harvest of perhaps 500 strong trees. Historically, however, the majority of the 4500 trees which did not survive until the final stage could also be made use of.

In a primary forest, the annual accumulation should be extremely similar. Albeit, because there is now output by wood harvest, the decomposition of dead wood equals the wood growth and the wood stock is more or less in equilibrium (Begon et al. 1996). Since more trees are in the second layer, the average annual growth is perhaps slightly lower. The stock available in a forest consisting of trees of different classes depends on the medium age. Amodern forest, consisting of one species and one age class has the aim of producing as much wood as possible. Therefore, the harvest of such an artificial forest, taken at the right time, should be higher than the wood stock of a primary forest. The medium annual growth of a primary forest is in all probability also less, due to numerous suppressed and weak growing trees in the lower layers. Referring to a medium annual growth of $5 \mathrm{~m}^{3} /$ ha per year, and a medium age of 50 years, a medium wood stock of $250 \mathrm{~m}^{3} /$ ha seems a realistic value to calculate with. Coppiced forests have a somewhat high annual growth rate because of their already well-developed root system. If they have always been coppiced with harvesting intervals of, for example 15 years, the stock accumulated can be estimated at $120 \mathrm{~m}^{3} / \mathrm{ha}$, taking into account a medium annual growth of $8 \mathrm{~m}^{3} /$ ha per year. With these short cycles, the loss through already dead branches or trees is minor.

\section{Disturbance and resilience}

Old world agriculture originates from the steppe belt. The cultivation of crops needs steppe or at least open conditions. In a forested area, the trees must be removed before beginning with agriculture. In contrast however, the forest is useful for other purposes such as hunting, gathering of fruit and mushrooms, pasture land and the gathering of wood. With regard to the used mass, wood was the most important primary product of human economics from the beginnings up to the modern age. From the first days of agriculture, there was a conflict as to how to manage the forest. In order to produce more food, it should disappear, while for other purposes it should remain. This conflict became difficult and dangerous from the Iron Age onwards when the requirement for wood increased as well as the population and the need for food.

In dry regions where the forest growth is near its limits, disturbances to the forest can be irreversible, in particular, when there is soil erosion as well. Temperate forests are resilient to disturbances: the forest recovers, passing through a successional series, as is observable in the pollen record (Müller 1962).

\section{Land-use systems}

For ancient agriculture, different land-use systems and therefore different strategies of dealing with the forest are in discussion (Bogaard 2004). In general, permanent and nonpermanent (shifting) cultivation can be distinguished. With permanent cultivation, the cultivated land is permanently free of trees and shrubs. The soil is free of wooden roots and tillage by ploughing or hoeing is possible. The remaining forest is clearly separated from the field. The influence of agriculture is indirect, at the most, for example, by removing material to fertilize the fields. When looking at nonpermanent cultivation, one has to distinguish between short interruptions combined with another kind of use, for instance as pasture land, which also prevents the re-establishment of 
trees and shrubs and long-term fallow phases which makes possible the return of the forest.

The need for, primarily forested, space, given a distinct population, differs a great deal at first view, although it is actually not all that different upon a second, closer view. Permanent cultivation without fertilisation results in low yields and therefore in large fields and large deforested areas. Permanent cultivation with fertilizer and short fallow phases requires medium- to large-size areas when the low yields as documented, for example, for the early modern period are borne in mind. The production of fertilizers requires animal grazing and grazed forests result in fewer trees and less tree-growth in the forest. According to the Forchtenberg results (Rösch et al. 2011), the question must be raised as to whether these areas could be managed without ploughs and animal power.

Shifting cultivation in the forest results in extremely high yields and therefore requires small fields. The rotation of the fields in the forest influences and changes the forest extensively and old, strong trees in particular can become scarce. The majority of the wood stock and the wood growth of the forest are consumed as fertilizer by burning.

\section{Wood use}

Wood species have varying qualities which can be used for different purposes. People in the past had a knowledge of this and it can therefore be assumed that they selected the wood based upon its aptitude for a specific purpose. This seems to be the case with tools. They preferred, for example, Taxus for bows, Viburnum for arrows and Fraxinus for handles. For the construction of houses, oak is the most suitable wood, due to its longevity and density. For log houses, conifers are more suitable, due to their straight stems without ramifications. When examining wood statistics, however, of the well- investigated Neolithic lake shore settlements of Hornstaad and Arbon at Lake Constance, Quercus is not the most frequent construction wood. In Hornstaad, Populus, Fraxinus, and Salix are more common, in Arbon Abies, Alnus and Fraxinus. This is the result of the fact that construction woods for houses or stockades are large and heavy and cannot be transported over long distances. If the material cannot be transported by water, it must be collected in the direct vicinity of the construction site. The short distances for transport were presumably more important than the quality. People used what was available locally and if a shortage of construction wood in Prehistory occurred it was on a local level.

The amount of wood used for construction depends on the house size, the construction type, the durability of the single construction part and the durability of the entire house. In addition, wood was needed for stockades as well as in a relatively small amount for tools.

For the wood demand for the large houses of the early and Middle Neolithic, experimental data can be referred to (Luley 1990, 1992). The medium longevity of each part is estimated at 5 years (Rösch 1994).
The amount of wood needed for fires for cooking, heating and firing pottery is difficult to calculate, but in any case it is higher than the need for construction wood (Kerig 2011).

After chopping, however, firewood must be dried at least one or two seasons in dry places protected from precipitation. This requires organisation and work. In contrast, however, particularly in a primary forest, dead and already dry wood, easy to chop and ready for burning is available in considerable amounts.

The dead wood of trees which are still standing serve as a perfect burning material. Dead wood from the ground is to a great extent destroyed by fungi with the amount depending on the exposure time and on the wood species. Among the woods of temperate Europe, Fagus decomposes the fastest, Quercus the slowest. Based on dry mass, the degree of composition and the remaining caloric content is related to the weight.

Firewood can be therefore in all probability disregarded in the calculation of wood balance for prehistory, particularly keeping in mind, that for this purpose branch wood can be used. This can be processed easier than trunks and is not included in the productivity balances of forests, which are only based on stem wood. The situation is different with high temperatures burning and therefore charcoal is needed for ore processing. The calculation by Rösch (1994) took firewood into account and assessed a total wood consumption of $15 \mathrm{~m}^{3}$ wood per household and year, of which $10 \mathrm{~m}^{3}$ was for firewood. We viewed this estimate as reasonable in spite of higher estimates by other authors (e.g. Pleinerova 1986).

\section{Consumption of wood - changes to the forest, a study from Lake Constance}

The best tool for studying the forest of the past is a pollen analysis (Firbas 1949; Berglund 1986; Lang 1994). The result of a pollen analysis of a peat or sediment sample is a list of identified pollen types. Each of this types is connected with a count, a number between 1 and many. On the base of these numbers percentages for each type can be calculated, or the pollen influx per year, when the analysis was carried out absolutely (adding and counting of a standard to a known sample size), and when a age model based on absolute dates exists. These are results of pollen analysis, albeit with a certain inaccuracy. However the reconstruction of vegetation based on those pollen results is an interpretation. To calibrate the pollen data to express vegetation cover, the relationship between vegetation and pollen precipitation must be studied for each landscape. There is a great deal of work about this topic in progress. Even without valid models of pollen emission and precipitation, it can be estimated that a species which increases its pollen amount in the sediment is also more frequent in the landscape and vice versa.

The Lake Constance region is perhaps the best investigated region in Europe, both in Prehistoric Archaeology and in Vegetation History. Of the numerous excavated Neolithic sites, Hornstaad in Germany and Arbon Bleiche III in Switzerland 


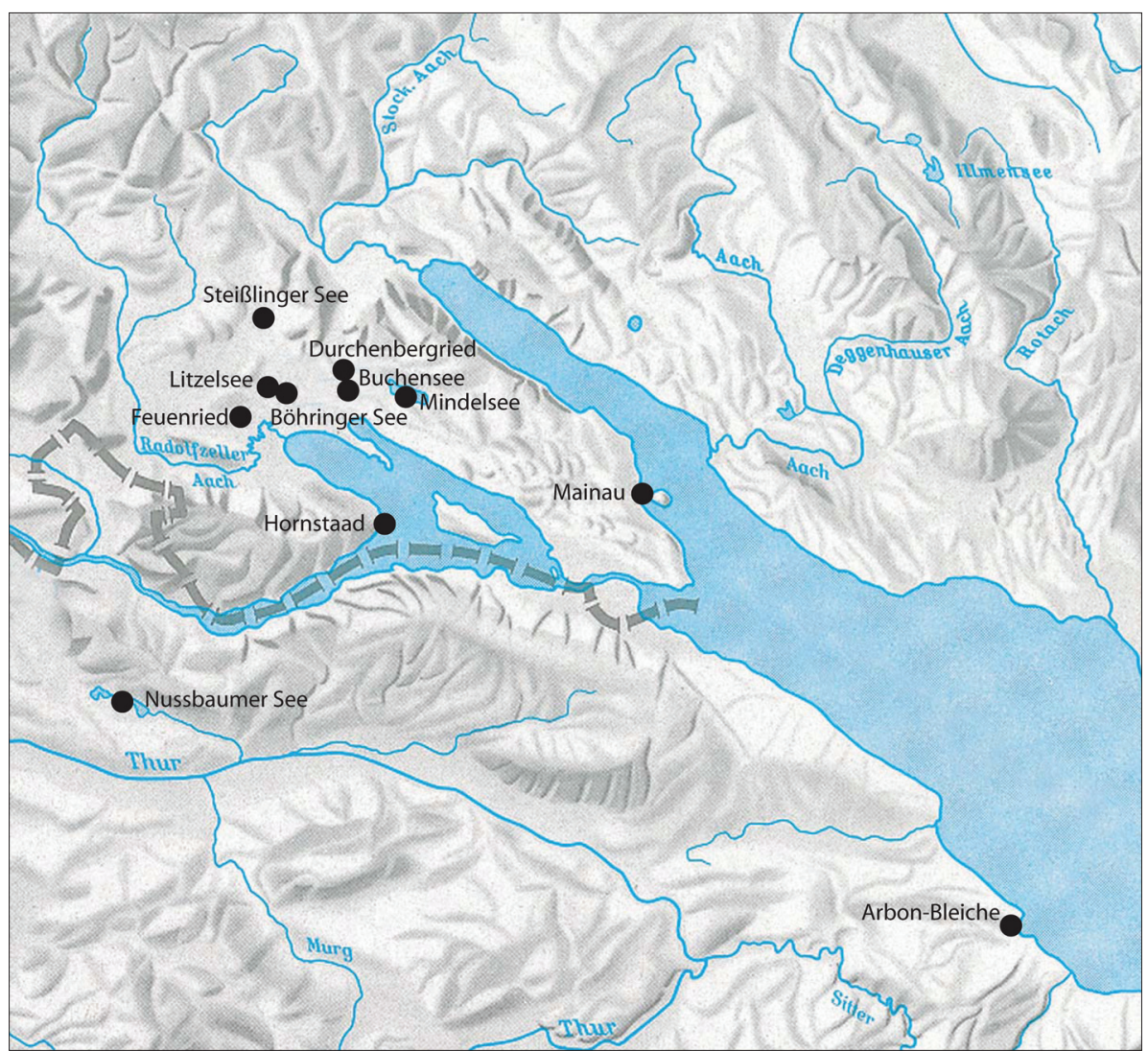

Figure 1. Prehistoric lake shore and pollen sites at Lake Constance mentioned in this paper.

have large data-sets regarding construction wood (Billamboz 2006; Sormaz 2004, Figure 1). From Arbon-Bleiche 3 as well as from Hornstaad-Hörnle I, considerable parts of the settlement were excavated, from Hornstaad-Hörnle II, III and $\mathrm{V}$ only small areas, the difference in which is also reflected in the total number of wood remains investigated. Whereas on the southern shore of the upper Lake Constance modern off-site pollen data is lacking, a great deal of data is available in the German part of the western Lake Constance region. They are from small lakes or mires or from the shallow water zone of Lake Constance itself (Figure 1). The vegetation development of these cores is at first view extremely similar. A detailed analysis, referring to patterns in time and space, is in progress. In this article we use as an example profile Hornstaad, consisting of 890 samples from a 14 m lake-marl core in the shallow water zone at lower Lake Constance (Rösch 1992; 1993; 1997). The Hornstaad profile is situated at the tip of a peninsula of Lower Lake Constance, which is divided into various bays. A comparison with several other profiles from the region provided proof that the profile can be regarded as typical, but with local aspects, revealing the characteristics of a small to medium size site according to the criteria of Sugita (1994) and Gaillard et al. (2008).

\subsection{On-site wood spectra}

The wood spectra of the dwellings of Hornstaad, mostly construction wood, covering a time span of 800 years, are quite similar (Figure 2) ${ }^{1}$ : The species most used are Populus,
Fraxinus, and Salix, followed by Quercus, Alnus, Corylus, and Fagus. Arbon Bleiche, situated in a different landscape where in all probability Abies was abundant, is different: Abies was used the most often. The next most abundant are Alnus and Fraxinus. All the others are fairly seldom.

Populus, Salix, Alnus and Fraxinus are light-demanding pioneer trees from wet or even occasionally flooded soils near the lake shore. They can be harvested locally. Quercus robur is also a tree of wet soils near the shore. The less frequent species, Corylus and Fagus, as well as Acer, grew preferentially beyond the flooded area near the shore, but because the slopes are rather steep, the distance from the settlement cannot be more than 50 or $100 \mathrm{~m}$.

\subsection{The off-site pollen record}

The pollen data of Hornstaad is presented as histograms, each column representing one century, showing the sum of seven to ten samples with a total upland pollen sum between 4,000 and 17,000.

Looking at the relationship between trees, shrubs, NAP, and micro-charcoal, the latter has higher values during all the settlement phases than before and between them (Figures 3 and 4). With the exception of HoIB, the tree pollen is decreased, and the shrub pollen is increased during the settlement phases, whereas the NAP shows no significant change.

Looking at the trees and shrubs, Betula and Alnus increase in the phase of HoIA/Ho III, whereas Fagus, Tilia and Ulmus 
Figure 2. Wood spectra from the Neolithic lake shore sites at Lake Constance.

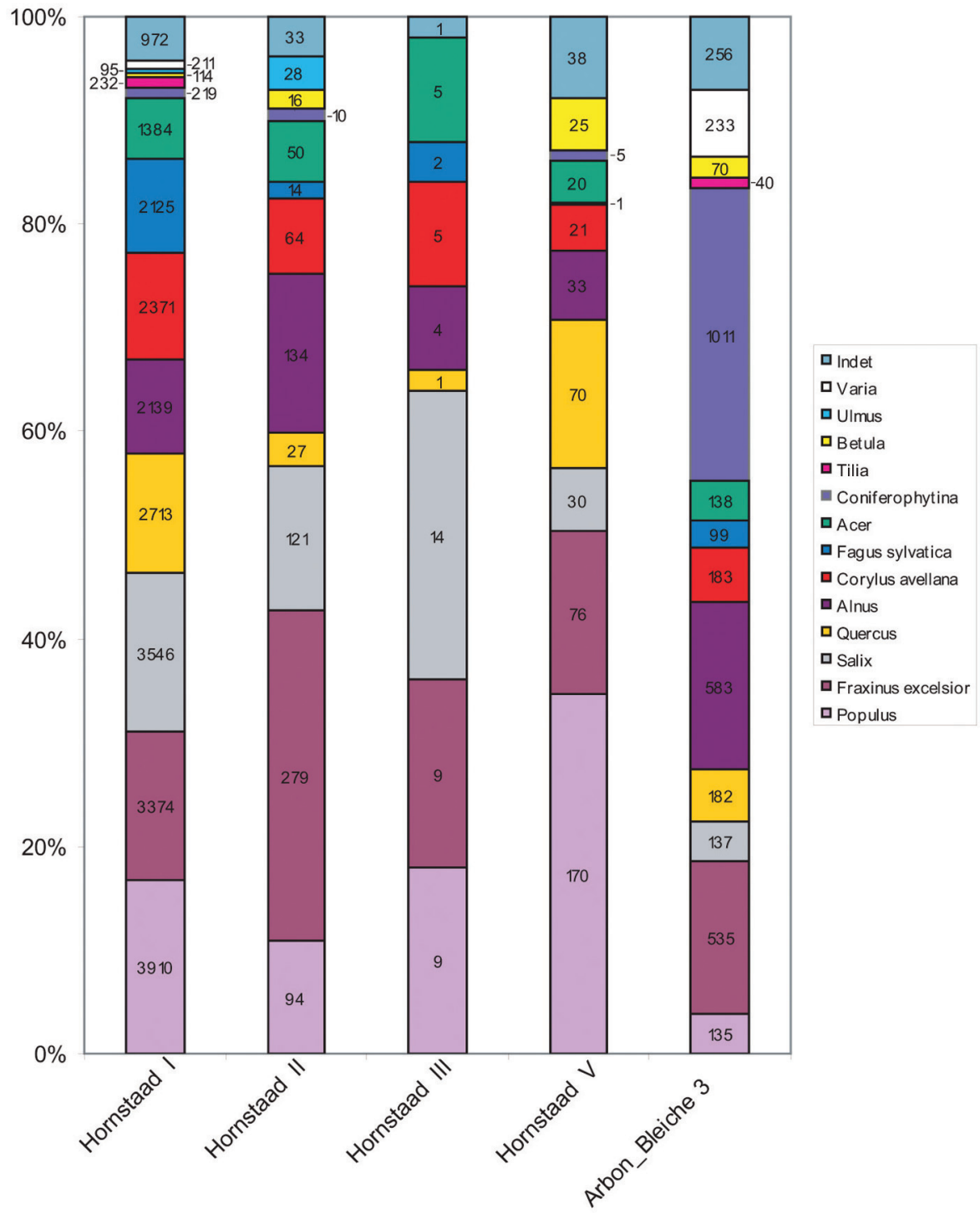

decrease, and Corylus, Fraxinus and Quercus remain more or less unchanged (Figure 5). In the phase of Ho II, there is an increase of Corylus, Fagus, Abies, and Tilia, a decrease of Betula, Ulmus, and Fraxinus, whereas Alnus and Quercus remain more or less unchanged. In phase Ho IB, Fagus and Quercus increase, and Corylus decreases, whereas the others show no clear change. The phase of Arbon-Bleiche III reveals an increase of Corylus, Quercus, and Fraxinus and a decrease of Fagus, Ulmus and Alnus, whereas the others seem unchanged.

In phase Ho V Corylus and Alnus increase, Fagus, Quercus, and Tilia decrease and the others remain unchanged.

Populus is so rare in the pollen record, that no change is traceable. The proportion of Acer and Salix is too small to be visible in Figure 5.

Figure 6 shows the percentages of Acer, based on the land pollen sum, Figure 7 presents the same for Salix.

Acer shows a decrease in the phases Ho IA/III, Ho II, Arbon and Ho V, but an increase in Phase Ho IB. Salix decreases in phase Ho IA/III, but increases in all the other phases.
Table 2 resumes the results of Figures 2-7 and combines the on-site wood and the off-site pollen results. In 21 cases the correlation between wood and pollen is negative. This means either a species becomes more abundant in the pollen record in spite of strong use, or it becomes less abundant in spite of weak use or no use at all. In 10 cases the correlation is positive. A strong use is combined with a decrease in the pollen record; weak or no use is combined with an increase. In 17 cases there is no correlation visible.

\section{Conclusion}

In conclusion, there is no correlation between wood exploitation and changes in the forest composition during the Late Neolithic at Lake Constance. The removal of wood as an impact factor on the forest can be disregarded. There were other human-induced factors which changed the forest.

This shall be illustrated with an example from the western Lake Constance region. During the late Neolithic occupation 


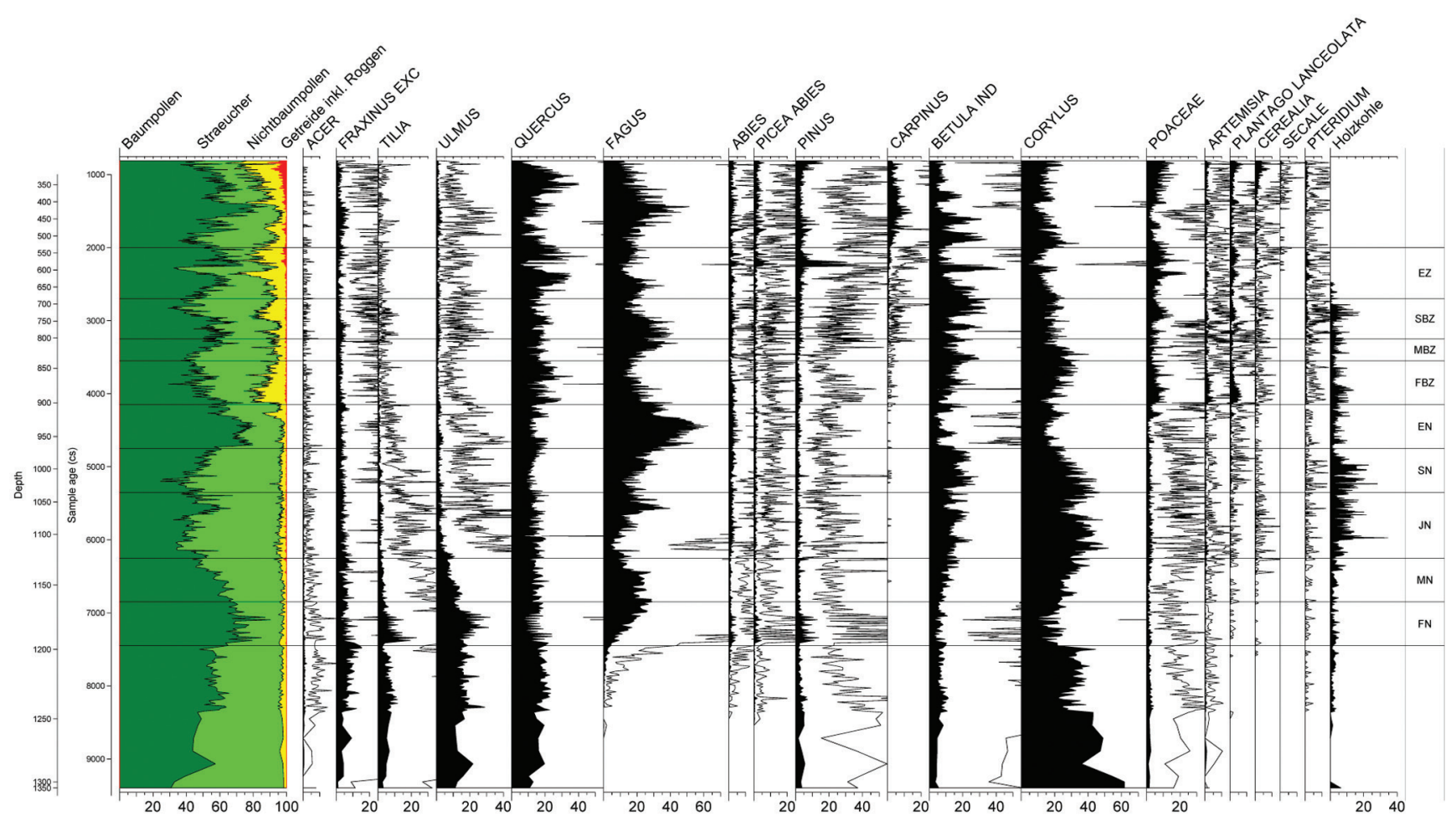

Figure 3. Simplified pollen diagram of Hornstaad; linear time axis B.P. cal.; calculation base of percentages total land pollen sum inclusive Alnus exclusive Cyperaceae.

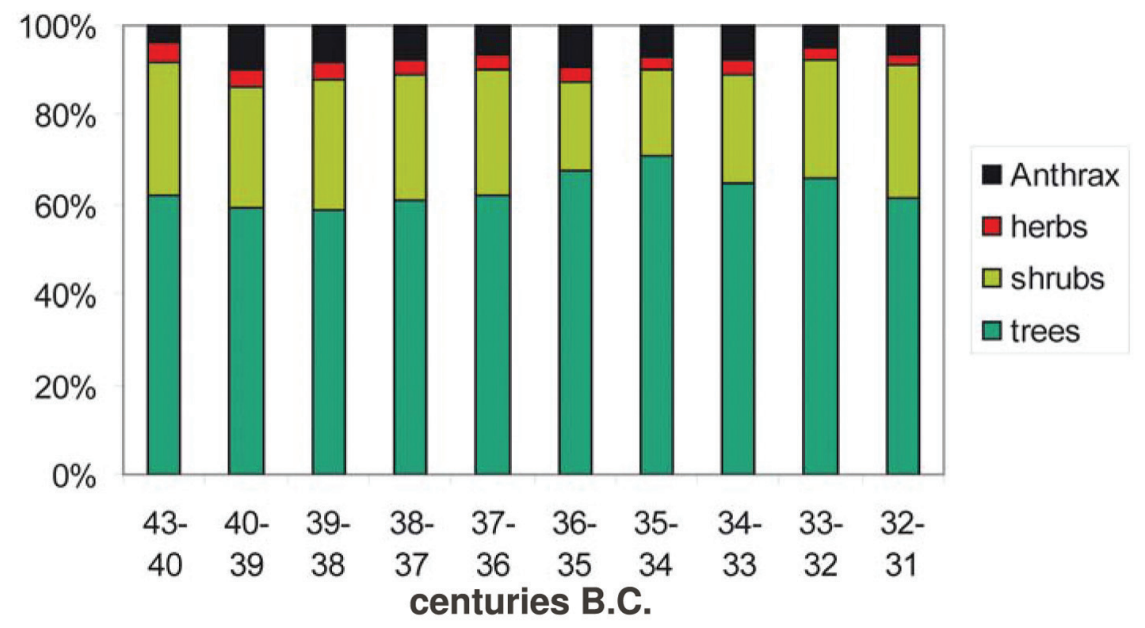

Figure 4. Pollen histogram of Hornstaad with 100 year time slides from 4300 to 3100 cal. B.C. cal. part A, main components: trees, shrubs, herbs and grasses, charred particles; calculated on the basis of the pollen sum of the included types.

phase, Fagus decreases from 25 to $5 \%$. If we therefore take shifting cultivation with slash-and-burn agriculture as the most plausible land-use model (Rösch 1987), up to $80 \%$ of the forested land or about 30,000 ha were used in turn for agriculture. Based on the Forchtenberg results concerning the wood needed for slash-and-burn agriculture and about the recovery time of the forest (Rösch et al. 2011), we can estimate $2 \%$ or 600 ha for crop-growing per year which, taking into account an average yield of $5000 \mathrm{~kg} / \mathrm{ha}$, would result in an overall yield of 3,000,000 kg crops, sufficient to feed 15,000 people. The resulting population density is about 30 people per $\mathrm{km}^{2}$.

Calculating with 5,000 houses for these 15,000 people and an annual need for wood of 15 , a total need of 75,000

$\mathrm{m}^{3}$ of wood would result. Assuming that at least $95 \%$ of the area was forested, albeit with coppiced forest in different states of regeneration, and calculating with an annual wood production of only $5 \mathrm{~m}^{3}$ as the worst case, an annual wood surplus of 22,500,000 $\mathrm{m}^{3}$ would result. Therefore, only 1/300 or $0.3 \%$ of the wood growing every year in the forest was used. The need for wood for construction, tools and for fires for cooking, heating and firing during the Neolithic could never have had an impact on the forest and a shortage of construction wood could only have occurred, if at all, with regard to distinct species and distinct size classes in the direct vicinity of the settlements.

If we postulate the shifting cultivation model and 600 ha fields in yearly cultivation, a need for $126,000,000 \mathrm{~kg}$ or 
Figure 5. Pollen histogram of Hornstaad with 100 year time slides from 4300 to 3100 cal. B.C. cal. part B, important trees and shrubs; calculated on the basis of the pollen sum of the included pollen types.

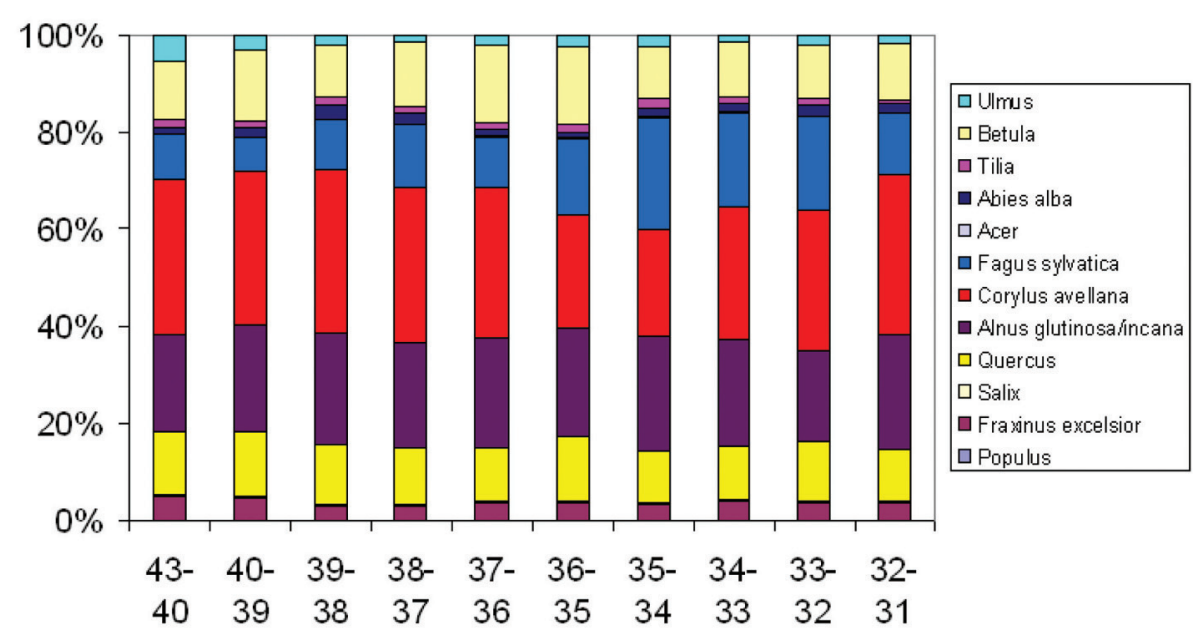

centuries B.C.
Figure 6. Pollen histogram of Hornstaad with 100 year time slides from 4300 to 3100 cal. B.C. cal. part C, Acer, percentages calculated on the basis of the upland pollen sum.

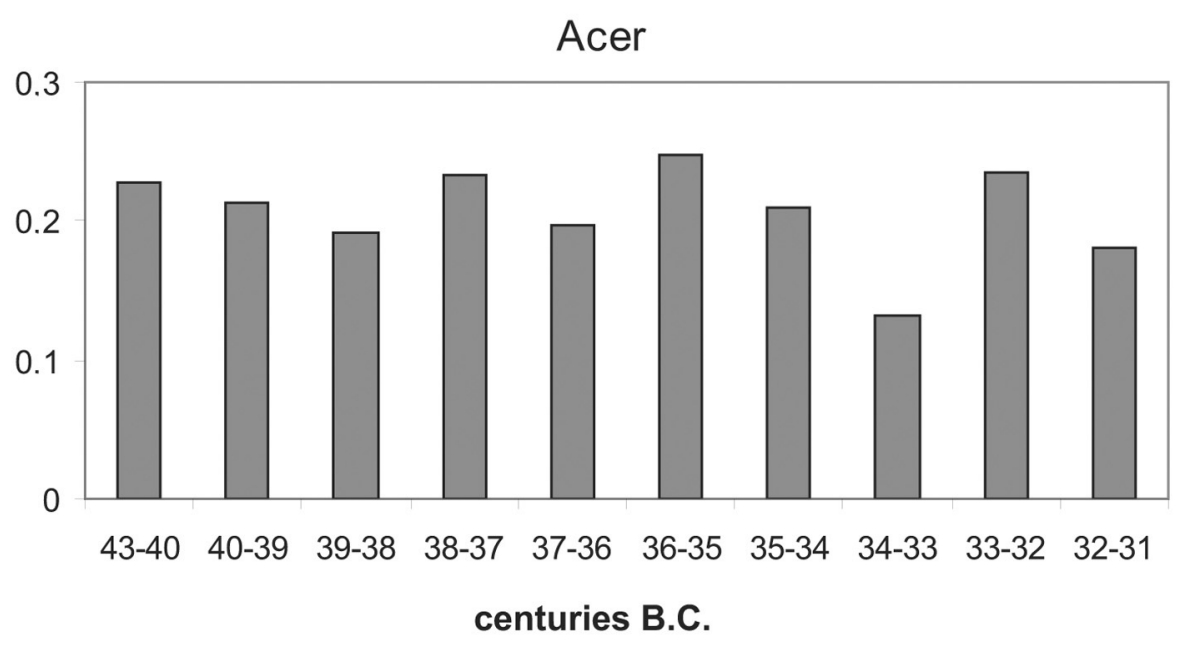

Figure 7. Pollen histogram of Hornstaad with 100 year time slides from 4300 to 3100 cal. B.C. cal. part C, Salix, percentages calculated on the basis of the upland pollen sum.

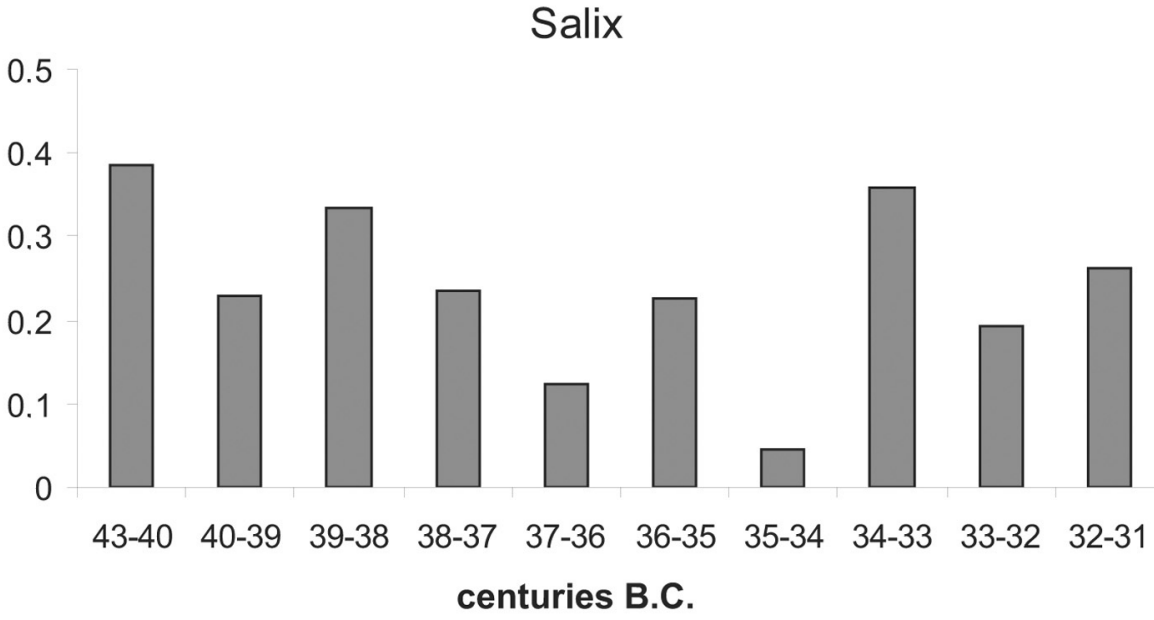


Table 1. Annual wood growth of different trees under optimal conditions, and the amount of stem wood available given a distinct harvest age, see Kramer (1988).

\begin{tabular}{lccc}
\hline Species & $\begin{array}{c}\text { Growth } \\
{\left[\mathbf{m}^{\mathbf{3} / \mathbf{h a}} \mathbf{a}\right]}\end{array}$ & $\begin{array}{c}\text { Harvest age } \\
{[\mathbf{a}]}\end{array}$ & $\begin{array}{c}\text { Stock } \\
{\left[\mathbf{m}^{\mathbf{3}} / \mathbf{h a}\right]}\end{array}$ \\
\hline Picea abies & 12.2 & 100 & 754 \\
Pinus sylvestris & 8.0 & 80 & 391 \\
Larix decidua & 9.1 & 80 & 455 \\
Abies alba & 12.0 & 140 & 836 \\
Fagus sylvatica & 8.6 & 140 & 794 \\
Quercus robur/petraea & 6.7 & 160 & 451 \\
Acer pseudoplantanus & 10.2 & 100 & 471 \\
Fraxinus excelsior & 6.6 & 100 & 384 \\
Alnus glutinosa & 8.5 & 60 & 283 \\
Betula & 4.9 & 80 & 212 \\
\hline
\end{tabular}

Table 2. Wood consumption and forest composition at Lake Constance during the Neolithic. + taxon increases in the pollen record - taxon decreases in the pollen record \pm taxon shows no change in the pollen record; dark-grey background: a positive correlation between wood-use and the change of ubiquity in the pollen record, light- grey background: a negative correlation between wood- use and the change of ubiquity in the pollen record, white background: no correlation between wood -use and the change of ubiquity in the pollen record

\begin{tabular}{|c|c|c|c|c|c|c|}
\hline Site & Century B.C. & Use strong & Use medium & Use weak & Use very weak & No use \\
\hline \multirow[t]{4}{*}{ Hornstaad, Hörnle I, III } & 40 & & & & & \\
\hline & & Populus? & Quercus \pm & Fagus - & Tilia - & \\
\hline & & Fraxinus \pm & Alnus + & Acer - & Betula + & \\
\hline & & Salix - & Corylus \pm & & $\begin{array}{l}\text { Abies + } \\
\text { Ulmus + }\end{array}$ & \\
\hline
\end{tabular}

\begin{tabular}{|c|c|c|c|c|c|c|}
\hline \multirow[t]{7}{*}{ Hornstaad, Hörnle II } & 39 & \multirow[b]{2}{*}{ Fraxinus - } & \multirow[b]{2}{*}{ Populus? } & \multirow[b]{2}{*}{ Corylus +} & \multirow[b]{2}{*}{ Quercus - } & \\
\hline & & & & & & \\
\hline & & & Salix + & \multirow[t]{5}{*}{ Acer - } & Fagus + & \\
\hline & & & Alnus + & & Abies + & \\
\hline & & & & & Betula - & \\
\hline & & & & & Ulmus - & \\
\hline & & & & & Tilia + & \\
\hline \multirow[t]{7}{*}{ Arbon, Bleiche III } & 34 & & & \multirow{7}{*}{$\begin{array}{l}\text { Quercus } \pm \\
\text { Corylus }+\end{array}$} & & \\
\hline & & Abies \pm & Fraxinus + & & Populus? & Ulmus - \\
\hline & & & Alnus \pm & & Salix + & \\
\hline & & & & & Acer - & \\
\hline & & & & & Fagus - & \\
\hline & & & & & Tilia - & \\
\hline & & & & & Betula \pm & \\
\hline \multirow[t]{5}{*}{ Hornstaad, Hörnle V } & $33-32$ & \multirow{5}{*}{ Populus? } & & \multirow{5}{*}{$\begin{array}{c}\text { Alnus }+ \\
\text { Salix }+ \\
\text { Betula } \pm \\
\text { Corylus }+\end{array}$} & \multirow{5}{*}{$\begin{array}{l}\text { Acer - } \\
\text { Abies - }\end{array}$} & \\
\hline & & & Fraxinus \pm & & & Fagus - \\
\hline & & & Quercus - & & & Tilia - \\
\hline & & & & & & Ulmus \pm \\
\hline & & & & & & \\
\hline Korrelation negative & 21 & & & & & \\
\hline Korrelation positive & 10 & & & & & \\
\hline no Korrelation & 17 & & & & & \\
\hline
\end{tabular}




\section{References}

BERGLUND, B. 1986: Handbook of Holocene Palaeoecology and Palaeohydrology. Wiley, Chichester.

BILLAMBOZ, A. 2006: Dendroarchäologische Untersuchungen in den neolithischen Ufersiedlungen von Hornstaad-Hörnle. Siedlungsarchäologie im Alpenvorland IX, Forschungen und Berichte zur Vor- und Frühgeschichte in Baden-Württemberg 98, 297-414.

BOGAARD, A. 2004: Neolithic Farming in Central Europe. An Archaeobotanical Study of Crop Husbandry Practises. Routledge, London/New York 2004.

BRAUN, H. J. 1982: Lehrbuch der Forstbotanik. Fischer, Stuttgart/New York.

ELLENBERG, H. 1996: Vegetation Mitteleuropas mit den Alpen. Ulmer, Stuttgart.

FIRBAS, F. 1949: Spät- und nacheiszeitliche Waldgeschichte Mitteleuropas nördlich der Alpen. Bd. 1, Allgemeine Waldgeschichte. Fischer, Jena.

HEGI, G. 1981: Illustrierte Flora von Mitteleuropa. Bd. I Gymnospermae, Angiospermae, Monocotyledonae 1, Teil 2. Parey, Berlin/Hamburg.

KERIG, T. 2011: “... und Eva span...”Zur Urgeschichte der geschlechtlichen Arbeitsteilung in arbeitswirtschaftlicher Perspektive. In: Fries, J. E. Rambuscheck, U. (eds), Von wirtschaftlicher Macht und militärischer Stärke, Beiträge zur archäologischen Geschlechterforschung, FrauenForschung - Archäologie 9, Münster, 17-36.

KRAMER, H.1988: Waldwachstumslehre. Parey, Hamburg/Berlin.

LANG, G. 1994: Quartäre Vegetationsgeschichte Europas. Fischer, Jena.

LEIBUNDGUT, H. 1993: Europäische Urwälder. Wegweiser zur naturnahen Waldwirtschaft. Haupt, Bern.

LEIBUNDGUT, H. 1982: Europäische Urwälder der Bergstufe. Haupt, Bern.

LOPEZ, J. A., BÜCKING, W. 1994: Textur, Waldstruktur und Naturverjüngung im Bannwald "Napf", Mitteilungen des Vereins für Forstliche Standortskunde und Forstpflanzenzüchtung Freiburg 37, 49-59.

LULEY, H. 1990: Die Rekonstruktion eines Hauses der Rössener Kultur im Archäologischen Freilichtmuseum Oerlinghausen. In: Experimentelle Archäologie in Deutschland. Archäologische Mitteilungen aus Nordwestdeutschland, Beiheft 4:31-44.

LULEY, H. 1992: Urgeschichtlicher Hausbau in Mitteleuropa. Grundlagenforschung, Umweltbedingungen und bautechnische Rekonstruktion. UPA 7, Bonn.
MAYER, H. 1984: Wälder Europas. Fischer, Stuttgart/New York.

MITSCHERLICH, G. 1978: Wald, Wachstum und Umwelt. Bd. 1, Sauerländer, Frankfurt.

MÜLLER, H. 1962: Pollenanalytische Untersuchung eines Quartärprofils durch die spät- und nacheiszeitlichen Ablagerungen des Schleinsees (Südwestdeutschland), Geologische Jahrbücher 79, 493-526.

RÖHRIG, E., BARTSCH, N., von LÜPKE, B. 2006: Waldbau auf ökologischer Grundlage. Ulmer, Stuttgart.

RÖSCH, M.1987: Zur Umwelt und Wirtschaft des Neolithikums am Bodensee - Botanische Untersuchungen in Bodman-Blissenhalde, Archäologische Nachrichtungen aus Baden 38/39, 42-53.

RÖSCH, M.1992: Human Impact as Registered in the Pollen Record: Some Results from the Western Lake Constance Region, Southern Germany, Vegetation History and Archaeobotany 1, 101-109.

RÖSCH, M 1993: Prehistoric Land Use as Recorded in a Lake-shore Core at Lake Constance, Vegetation History and Archaeobotany 2, 213-232.

RÖSCH, M. 1994: Gedanken zur Auswirkung (prä)historischer Holznutzung auf Wälder und Pollendiagramme, Diss. Bot. 234, (Festschrift Gerhard Lang), 447-471.

RÖSCH, M.1996: Holocene Sediment Accumulation in the Shallow Water Zone of Lake Constance, Arch. Hydrobiol./Suppl. 107 (Monographic Studies), 4 (Stuttgart), 541-562.

RÖSCH, M., BIESTER, H., BOGENRIEDER, A., ECKMEIER, E., EHRMANN, O., GERLACH, R., HALL, M., HARTKOPF-FRÖDER, C., HERMANN, L., KURY, B., SCHIER, W., SCHUlZ, E. 2011: Spätneolithischer Ackerbau im Experiment - eine Zwischenbilanz nach 12 Jahren Forchtenberg. In: Bork, H. R., Meller, H., Gerlach R. (Eds): Umweltarchäologie - Naturkatastrophen und Umweltwandel im archäologischen Befund, Tagungen des Landesmuseums für Vorgeschichte Halle (Saale) 6, 2011, 175-192.

SORMAZ, T. 2004: Absolute Datierung durch Dendrochronologie und $\mathrm{C}^{14}$-Analysen. In: Jacomet, S., Leuzinger, U., Schibler J. (Eds): Die jungsteinzeitliche Ufersiedlung Arbon-Bleiche 3, Umwelt und Wirtschaft, Archäologie im Thurgau 12, Frauenfeld 2004, 105-111.

STRASBURGER, F. 1983: Lehrbuch der Botanik für Hochschulen, begründet von E. Strasburger, F. Noll, H. Schenk, A.F.W. Schimper neubearbeitet von D. von Denffer, H. Ziegler, F. Ehrendorfer, A. Bresinsky. Fischer, Stuttgart/New York.

WALTER, H., BRECKLE, S. W. 1983: Ökologie der Erde. Band 1, Ökologische Grundlagen in globaler Sicht. Fischer, Stuttgart. 
